\title{
EFFECTS OF DIETARY PROTEIN LEVELS WITH OR WITHOUT SYNTHETIC AMINO ACIDS AND ENZYME SUPPLEMENTATION ON PERFORMANCE OF BROILER CHICKENS
}

\author{
R.M.S. Emam \\ Poultry Production Department, Faculty of Agriculture, Fayoum University, Egypt.
}

(Received 28/12/2017, accepted 4/2/2018)

\section{SUMMARY}

\begin{abstract}
$\mathrm{T}$ This experiment was conducted to study the effect of using two levels of (recommended (R), R-2\%) crude protein $(\mathrm{CP})$ supplemented with or without the requirements of methionine and lysine (Met. and Ly.) and each with two levels (0.00 and $0.10 \%)$ of Avizyme 1500 in $2 \times 2 \times 2$ factorial arrangement (giving eight dietary treatments) on growth performance of broiler chickens (Ross strain). Accordingly, a total numbers of 192 one-day old unsexed Ross broiler chickens were initially fed a control diet for five days. At six days of age, chicks were randomly allotted to the dietary treatments, birds were divided into eight treatments ( 24 birds each), each treatment contained three replicates of eight birds each. Results obtained could be summarized in the following: The main effects of level of $\mathrm{CP}$ had insignificant effect on live body weight (LBW), live body weight gain (LBWG), feed intake (FI), feed conversion (FC) and performance index (PI) during finisher ( 25 to 41 ) and overall experimental periods (6 to 41 days). Level of CP had significant effect on crude protein conversion (CPC) during the period from 6 to 41 days, chicks fed diet containing $\mathrm{R}$ had the worst CPC during same period. Chicks fed adequate amounts of amino acids (AA) supplement diets recorded significantly higher PI value during the period from 6 to 41 days, while, recorded significantly the worst values of $\mathrm{FC}$ and $\mathrm{CPC}$ during the same period. Level of AA had insignificant effect on LBW, LBWG and FI during overall experimental period. Neither enzyme addition nor interaction between level of CP, AA and enzyme addition had any significant effect on LBW, LBWG, FC, CPC and PI during the period from 6 to 41 days. No significant differences due to level of CP or AA on blood constituents, except, red blood cells count (RBCs) which was significantly affected. Chicks fed diet containing R-2\% CP or diet containing inadequate amounts of AA had higher value of RBCs. No significant differences due to enzyme addition and interaction effect of dietary treatments on blood constituents, except, interaction effect on neutrophils\% (segment) which was significantly affected. Neither level of CP and enzyme addition nor interaction between level of CP, AA and enzyme addition had any significant effect on slaughter parameters $\%$ and tibia weight and ash\% at the end of the finishing period. Level of CP, AA and interaction between level of $\mathrm{CP}$, AA and enzyme addition had insignificantly affected chemical composition of broiler meat. Chicks fed diet containing R-2\% supplemented with the requirements of Met. and Ly. with $0.10 \%$ of Avizyme had the best economical and relative efficiency values during the period from 6 to 41 days of age, as compared with those fed the control diet and other treatments. It can be concluded that, CP can be reduced from the recommended level by $2 \%$ and supplement these diets with either Met. and Ly or Avizyme without affecting performance. Besides, using such diets reduces feed cost and $\mathrm{N}$ pollution.
\end{abstract}

Keywords: crude protein, methionine, lysine, enzyme and broiler performance.

\section{INTRODUCTION}

Poultry production in Egypt has become one of the biggest agriculture industries and its improvement is a major goal of broiler producers. Also, the constant increase in demand for poultry meat by consumers requires an increase in production capacity (Recoules et al., 2017). On the other hand, the rapid growth of modern broiler strains, coupled with lower prices, however, feed costs account for approximately $60-75 \%$ of broiler production costs, especially dietary protein sources (Khalaji et al., 2016 and Asadi Kermani et al., 2017).

So, efforts to reduce dietary protein level have been the subject of numerous investigators. Low protein diets supplemented with the requirements of essential amino acids (EAAs) are recommended for poultry reared in normal and heat stress conditions (Aftab et al., 2006 and Vieira et al., 2016). Using 
such diets reduces feed cost, reduces the risk of $\mathrm{N}$ pollution of the environment through reducing $\mathrm{N}$ excretion by the birds (Vieira et al., 2016). Reduced $N$ excretion lowers ammonia level in the poultry house (this may also reduce sticky and wet litter, hock burns and breast blisters), thus reducing excrete excess nitrogen in the form of uric acid (Mahmood et al., 2017) and lowers the energetic efficiency of protein use as an energy source.

Ferguson et al. (1998) demonstrated with broilers that litter $\mathrm{N}$ could be reduced more than $16 \%$ when dietary crude protein (CP) was reduced by $2 \%$, while maintaining adequate levels of dietary amino acids (AA). Although some investigators believed they do not maintain the same performance as high protein diets (Aletor et al., 2000 and Abd El-Gawad et al., 2004). Crude protein in the diets can be reduced from the recommended level by 3-4\% than standard dietary recommendations level and supplement these diets with adequate amounts of synthetic AA (i.e., methionine and lysine (Met. and Ly.)) without affecting performance (Abdallah, 2005), this has been proven to be economical and has no negative impact on performance. Moreover, it reduces nitrogen pollution by approximately 24-34\%. Also, the majorities of the published papers indicated that feeding poultry low protein diets supplemented with AA maintain the same performance as that obtained from high protein diets. However, Colonago et al. (1991) concluded that optimal performance of starter and grower could not be achieved with low protein diets supplemented with crystalline AA. Hence, great efforts will be directed to maximize the utilization of low protein diets. Consequently, supplementing low protein diets with mono or multi-enzymes may can be alternative way to improve broiler chicks performance and economical efficiency in the diet of broilers fed either a variety of cereals and protein sources or a nutrient deficient diet.

Feed enzymes have shown positive effects on animal performance, protein nutrition and physiology, animal welfare and the environment (Selle et al., 2013) and the benefits of feed enzymes have proved to be more conspicuous in non conventional diets (Mahmood, et al., 2017; Pan et al., 2017 and Radfar et al., 2017). Additionally, The use of exogenous enzymes improving feed efficiency, performance and environmental quality (Ding et al., 2016). Improvement in feed conversion (FC) of broilers by supplemental xylanase, amylase and protease (Amerah et al., 2017 and Singh et al., 2017).

In addition, exogenous proteases can improve AA utilization and enhance the digestibility of AA (Cowieson and Roos, 2014, Wang et al., 2006 and Ding et al., 2016) resulting in better growth performance. Ghazi et al. (2003) and Mahmood et al. (2017) reported that growth performance and protein utilization were improved in broilers fed exogenous protease supplemented diets. Pan et al. (2016) and $\mathrm{Xu}$ et al. (2017) reported that, a possible way to decrease the $\mathrm{N}$ pollution by enhancing $\mathrm{N}$ digestibility and reducing $\mathrm{N}$ excretion in animal production is supplementation of exogenous proteases. Previous studies have explored the use of exogenous proteases in low protein diets. In this respect, Freitas et al. (2011); Liu et al. (2015) and Liu et al. (2017) reported that protease supplementation in low CP diets resulted in improved feed efficiency in broilers, however, Freitas et al. (2011) reported that protease supplementation had no effects on performance, regardless of diet protein levels. However, other studies have reported inconsistent results (Naveed et al., 1998) in broiler diets. Zanella et al. (1999) reported that enzyme supplementation should allow for a reduction in CP formulation and those AA individuals were not all improved by supplementation.

The objective of this study was to evaluate the effect of using two levels (recommended (R), R-2\%) of CP supplemented with or without the requirements of Met. and Ly. and each with two levels ( 0.00 and $0.10 \%$ ) of Avizyme 1500 on growth performance of broiler chickens (Ross strain).

\section{MATERIALS AND METHODS}

This study was carried out at the Poultry Research Station, Ministry of Agric. and Land Recl., Regional Councils for Agricultural Research and Extension, Fayoum, Egypt, during the period from January to February, 2016. Chemical analyses were performed in the laboratories of Poultry Production Department, Faculty of Agriculture, Fayoum University according to the procedures outlined by A.O.A.C. (1990). This experiment was conducted to study the effect of using two levels of ((R), R-2\%) $\mathrm{CP}$ supplemented with or without the requirements of Met. and Ly. and each with two levels $(0.00$ and $0.10 \%$ ) of Avizyme 1500 in $2 \times 2 \times 2$ factorial arrangement (giving eight dietary treatments) on growth performance of broiler chickens (Ross strain). Accordingly, a total numbers of 192 one-day old unsexed Ross broiler chickens were initially fed a control diet for five days. At six days of age, chicks were individually weighed to the nearest gram (start of experiment), wing-banded and randomly allotted to the 
dietary treatments, birds were divided into eight treatments (24 birds each), each treatment contained three replicates of eight birds each. Chicks were raised in electrically heated batteries with raised wire mesh floors and had a free access of mach feed and fresh water from nipple drinkers (2 nipples/cage) throughout the experiment.

The experimental treatments were as follows:

$\begin{array}{ll}\text { 1. Chicks were fed the control diet }\left(\mathrm{T}_{1}\right) . & \text { 2. } \mathrm{T}_{1}+0.1 \% \text { Avizyme. }\end{array}$

3. $T_{1}$ without the requirements of Met. and Ly. supplementation.

4. $\mathrm{T}_{1}$ without the requirements of Met. and Ly. supplementation $+0.1 \%$ Avizyme. 5. $\mathrm{T}_{1}-2 \% \mathrm{CP}$. 6. $\mathrm{T}_{1}-2 \% \mathrm{CP}+0.1 \%$ Avizyme. $7 . \mathrm{T}_{1}-2 \% \mathrm{CP}$ without the requirements of Met. and Ly. supplementation.

8. $\mathrm{T}_{1}-2 \% \mathrm{CP}$ without the requirements of Met. and Ly. supplementation $+0.1 \%$ Avizyme.

The composition and calculated analyses of the experimental diets (without Avizyme supplementation) are presented in Table (1). The experimental diets were supplemented with minerals and vitamins mixture, to cover the recommended requirements according to the strain catalog recommendations and were formulated to be iso-caloric. A commercial arabinoxylanase preparation (Avizyme 1500) was included in all dietary treatments, used at a rate of $1 \mathrm{~kg} /$ tonne $(0.1 \%)$ of complete feed. Avizyme 1500 used in this study were purchased from Multi veta, Company, Egypt. It is a multienzyme preparation that includes $150 \mathrm{U} / \mathrm{g}$ endo-1,3(4)-beta-glucanase, $300 \mathrm{U} / \mathrm{g}$ endo-1,4 beta xylanase EC 3.2.1.8; $4000 \mathrm{U} / \mathrm{g}$ subtilisin (protease) EC 3.4.21.62; $400 \mathrm{U} / \mathrm{g}$ alpha amylase EC 3.2.1.1; $25 \mathrm{U} / \mathrm{g}$ polygalacturonase (pectinase) EC 3.2.1.15.

Batteries were placed into a room provided with a continuous light ( $23 \mathrm{~h} / \mathrm{d}$ up to 41 days of age) and fans for ventilation. The experimental birds were reared under similar environmental conditions (open system), and were fed with broiler starter diet from six to 12 day, broiler grower diet from 13 to 24 day, and broiler finisher diet from 25 day to the end of the experiment at 41 day of age. Light was provided for $23 \mathrm{~h} / \mathrm{d}$. Room temperature on day 0 was $35^{\circ} \mathrm{C}$ and $33^{\circ} \mathrm{C}$ at the end of first week and decreased approximately $2^{\circ} \mathrm{C}$ per week until $23^{\circ} \mathrm{C}$ was reached, according to standard poultry rearing practices. Batteries were placed into a room provided with continuous fans for ventilation, the vaccination program adopted by recommended requirements according to standard commercial guidelines. Birds were individually weighed to the nearest gram at $6,12,24$ and 41 days of age intervals during the experimental period.

At the same time, feed consumption was recorded and feed conversion ( $\mathrm{FC}, \mathrm{g}$ feed/g gain) and live body weight gain (LBWG) were calculated. Crude protein conversion (CPC), caloric conversion ratio (CCR) and performance index (PI) was calculated according to the equation described by North (1981) as follows: PI $=(\mathrm{LBW}, \mathrm{Kg} / \mathrm{FC}) \times 100$. Accumulative mortality rate was obtained by adding the number of dead birds during the experiment divided by the total number of chicks at the beginning of the experimental period (mortality\% was within normal limits and not related to treatments studied).

At the end of the finishing period (41 days of age), slaughter tests were performed using three chicks around the average LBW of each treatment. The birds were on feed withdrawal overnight (approximately 16h), then individually weighed to the nearest gram, and slaughtered by severing the jugular vein. After four minutes bleeding time, each bird was dipped in a water bath $\left(80^{\circ}\right)$ for $30 \mathrm{~s}$, and feathers were removed mechanically. After the removal of head, carcasses were manually eviscerated (by the same person to ensure uniformity of cuts) to determine some carcass traits, dressing\% (eviscerated carcass without head, neck and legs) and total giblets\% (gizzard empty, liver, heart and spleen). The eviscerated weight included the front part with wing and rear part. The abdominal fat was removed by hand from the parts around the viscera and gizzard, and was weighed to the nearest gram. The bone of front and rear were separated and weighed to calculate meat percentage. The meat without the skin from each part was weighed and blended using a kitchen blender. At the time of slaughter test, individual blood samples were taken from three birds of each treatment to determine hematological and biochemical characteristics of blood. Chemical analyses of representative samples of the carcass meat (without skin) were carried out to determine DM, CP ( $\mathrm{N} \times$ 6.25), EE and ash contents according to the methods of A.O.A.C.(1990). Nitrogen free extract (NFE) was calculated by difference. 
Table (1): Composition and analyses of the experimental diets.

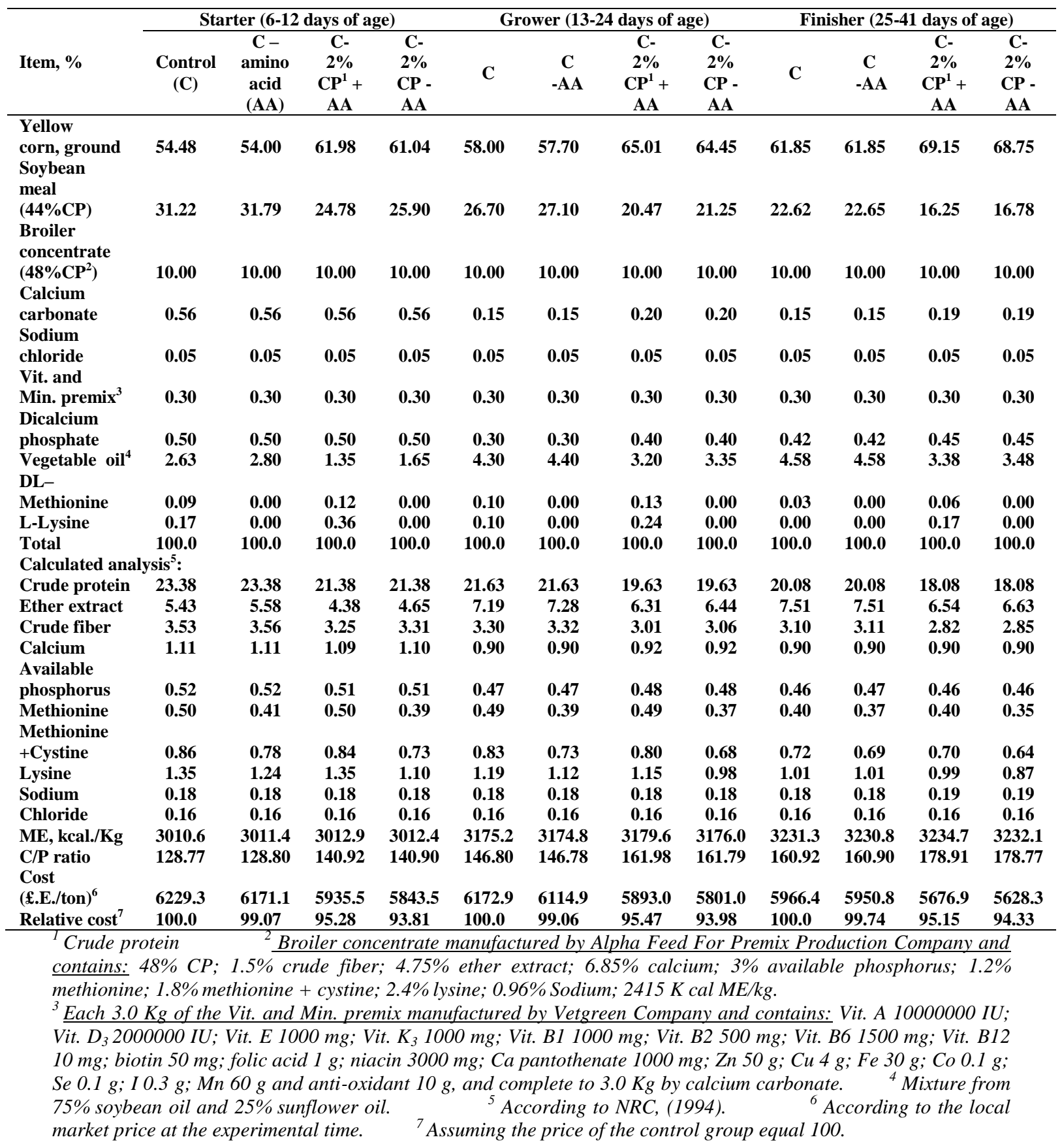

The right tibia bone was collected to obtain bone ash values according to the method of Martinez et al. (2006). Tibias were pooled by replicate groups and autoclaved and adhering tissue was removed. Then bones were dried for $24 \mathrm{~h}$ at $100^{\circ} \mathrm{C}$ and weighed, tibia relative weight as a percentage of LBW was calculated, and then dry-ashed for $24 \mathrm{~h}$ in a $600^{\circ} \mathrm{C}$ muffle furnace. Ash weight was expressed as a percentage of dried tibia weight. The economic efficiency was calculated as the price of live body weight-total costs of raising a broiler as relative to total raising costs which was estimated based upon local current prices at the experimental time. Statistical analysis of results was performed using the General Linear Models (GLM) procedure of the SPSS software (version 16, SPSS Inc., Chicago, IL), according to the follow general model:

$$
\mathrm{Y}_{\mathrm{ijkl}}=\mu+\mathrm{P}_{\mathrm{i}}+\mathrm{A}_{\mathrm{j}}+\mathrm{E}_{\mathrm{k}}+\mathrm{PA}_{\mathrm{ij}}+\mathrm{PE}_{\mathrm{ik}}+\mathrm{AE}_{\mathrm{jk}}+\mathrm{PAE}_{\mathrm{ijk}}+\mathrm{e}_{\mathrm{ijk}}
$$

Where: 
$\mathrm{Y}_{\mathrm{ijkl}}$ : observed value.

$\mu$ : overall mean.

$\mathrm{P}_{\mathrm{i}}$ : $\quad$ level of CP effect (i: recommended (R), R-2\%)

$\mathrm{A}_{\mathrm{j}}$ : level of AA (adequate and inadequate)

$\mathrm{E}_{\mathrm{k}}$ : $\quad$ enzyme supplementation effect (k: 0.00 and $0.10 \%$ ).

$\mathrm{PA}_{\mathrm{ij}}$ : interaction effect of level of $\mathrm{CP}$ by level of AA addition.

$\mathrm{PE}_{\mathrm{ik}}$ interaction effect of level of $\mathrm{CP}$ by enzyme supplementation.

$\mathrm{AE}_{\mathrm{jk}}$ : level of $\mathrm{AA}$ addition by enzyme supplementation effect.

$\mathrm{PAE}_{\mathrm{ijk}}$ : level of CP by level of AA by enzyme supplementation effect.

$\mathrm{e}_{\mathrm{ijkl}}$ : random error.

Treatment means indicating significant differences $(\mathrm{P} \leq 0.01$ and $\mathrm{P} \leq 0.05)$ were tested using Duncan's multiple range test (Duncan, 1955).

\section{RESULTS AND DISCUSSION}

\section{1-Productive performance:}

Effect of using two levels (R, R-2\%) of CP supplemented with or without the requirements of Met. and Ly. and each with two levels (0.00 and $0.10 \%)$ of Avizyme 1500 on LBW and LBWG of Ross strain broiler chicks during the period from 6 to 41 days of age are presented in Table (2).

Table (2): Effect of dietary protein levels with or without synthetic amino acids and enzyme supplementation on live body weight $(\mathrm{LBW}, \mathrm{g})$ and live body weight gain (LBWG,g) of broiler chickens.

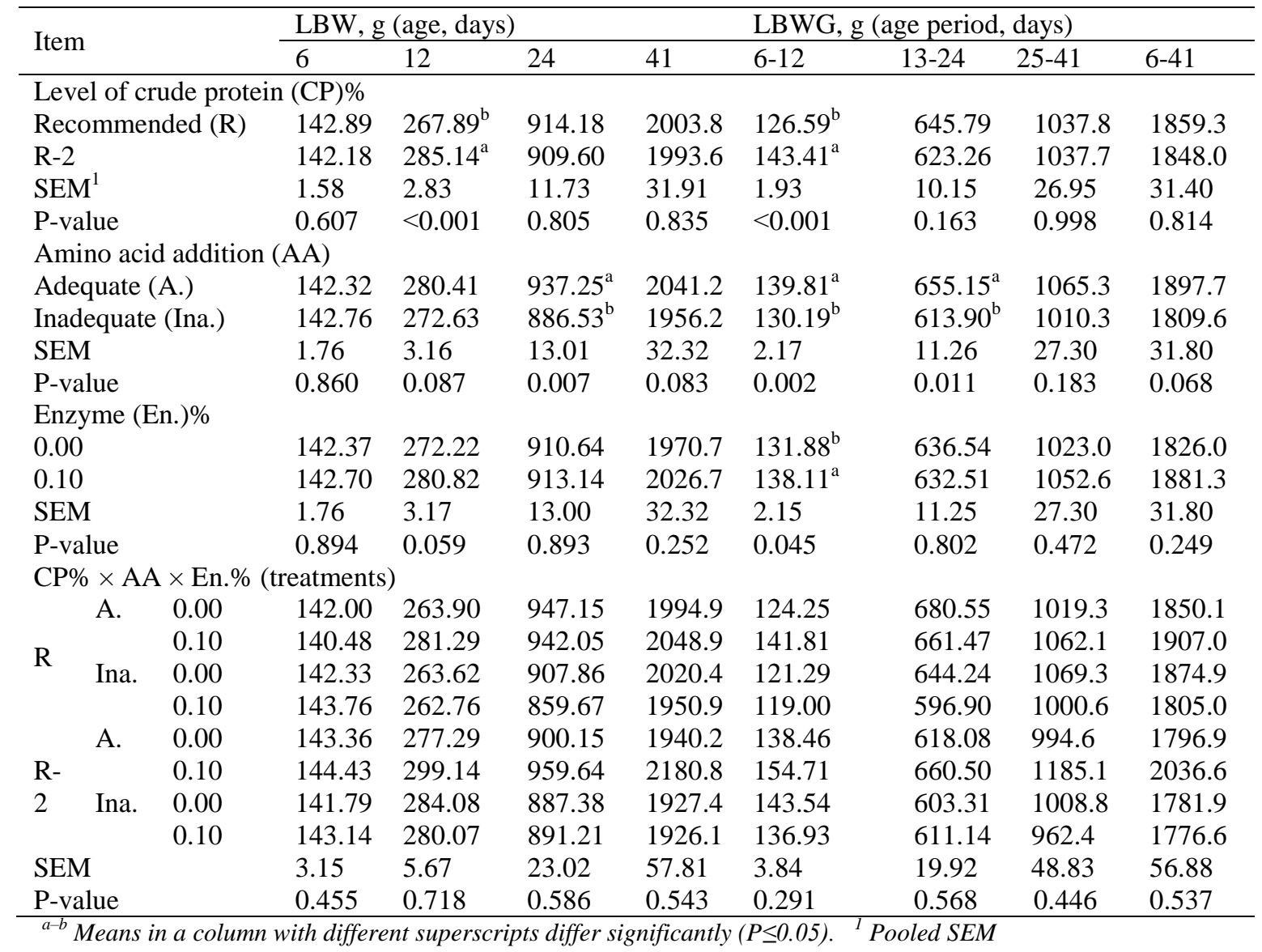


Data presented in Table (2) indicate the main effect of level of CP was significant $(\mathrm{P} \leq 0.01)$ for LBW at 12 days and LBWG during the period from 6 to 12 days, however, level of CP had insignificant effect on LBW and LBWG during the other periods studied. Chicks fed diet containing recommended level of CP $-2 \%$ had heavier LBW and higher LBWG during the previous periods, while, chicks fed diet containing $\mathrm{R}$ have lower values (Table 2). In this respect, many strategies have been assessed to use the low CP diets for broiler chickens without negative effects on growth performance (Parr and Summers, 1991 and Si et al., 2004). Also, in the studies of Kerr and Kidd (1999) suggest reduction of CP by two percentage units had no impact on daily LBWG or FC compared to birds fed the positive control diet since this level of $\mathrm{CP}$ reduction results in amino acid levels being relatively close to current recommendations. Garcia et al. (2000) reported that reducing dietary CP down to $19 \%$ insignificant effect on broiler performance.

Conversely, these results were unsupported by the findings of Asadi Kermani et al. (2017) who reported that lowering dietary $\mathrm{CP}$ concentration led to an increase in LBW ( $\mathrm{P} \leq 0.03)$. Moreover, Angel et al. (2011); Freitas et al .(2011); Ragab et al. (2012) and Ding et al. (2016) indicated that growth performance significantly decrease with reduction of CP contents of the diet than those fed diets containing recommended level. Also, Abd El-Gawad et al. (2004) and Waldroup et al. (2005) reported that broiler chicks fed on optimum level of CP showed significantly $(\mathrm{P} \leq 0.05)$ higher LBW and LBWG value during the experimental periods, when compared with suboptimum level of $\mathrm{CP}$, while, supplementing low protein diets with growth promoters or EAA partially improved the loss in LBWG. Further, in a study by Kamran et al. (2008) also noted that, although the birds consumed the same amount of protein and energy due to increased FI, there was a significant depression in LBWG of the birds with the reduction in dietary $\mathrm{CP}$ level during grower, finisher and overall experimental periods.

Concerning AA addition, the results cleared that chicks fed adequate amounts of AA supplement diets recorded significantly $(\mathrm{P} \leq 0.01)$ higher LBW at 24 days and LBWG values during the periods from 6 to 12 and 13 to 24 days. However, AA addition had insignificant effect on LBW and LBWG during the other periods studied. Similarly, Aletor et al. (2000) demonstrates that the growth of the grower broiler chicken is unaffected by decreasing dietary CP from 22.5 to $15.3 \%$ when such diets are supplemented with EAAs that meet the minimum NRC (1994) specifications. However, the increased feed consumption in the low protein diets led to a corresponding decrease in FC. Also, Schutte (1987) and Parr and Summers (1991) shown that optimal performance can be reached by supplementing diets with synthetic AA. By contrast, Moran et al. (1992) and Kamran et al. (2008) found that maximum performance cannot be reached by fortifying low protein diets with synthetic AA. However, Waldroup et al. (2006) demonstrated that reduction of more than $0.10 \%$ Met from current values could be tolerated without adversely affecting LBWG or FC.

Neither enzyme addition nor interaction between level of CP, AA and enzyme addition had any significant effect on LBW, LBWG, FC, CPC and PI during all periods studied, except, enzyme addition with LBWG and PI during the period from 6 to 12 days which was significantly affected (Tables 2 and 3 ). Inclusion of Avizyme 1500 which contain (4000 U/g subtilisin (protease)) in broiler diet at $0.1 \%$ caused a significant $(\mathrm{P} \leq 0.05)$ increase in LBWG and PI during the previous period. Numerically, as shown in Tables (2 and 3), enzyme supplementation increase LBW at 24 and 41 days, LBWG, FI and PI during the periods from 25 to 41 and 6 to 41 days compared with those fed enzyme un-supplement diet $(0.0 \%)$, however, these did not reach a level of statistical significance (the improvement in LBW and LBWG may be attributable to the effect of enzyme on the utilization of nutrients (protein, fat and carbohydrate digestibility) affecting growth). Many studies have reported adding enzyme blends containing proteases to the poultry diet (Rahman et al., 2009). In this respect, Vieira et al. (2016) reported that, in the case of endogenous proteases, peptide bond specificity directly affects the rate of protein hydrolysis and the quantity of peptides and AA released and made available for absorption.

Data presented in Table (3) indicated that level of CP was insignificant effect of FI during all periods studies except the period from 6 to 12 days of age which was significantly affected. Chicks fed diet containing R-2\% CP had higher value of FI only during the starter (6 to 12 days) period (Table 3). This observation was disagreement with reports by Kamran et al. (2008) who reported that FI was linearly increased with reduced CP diets during grower, finisher and overall periods. Likewise, Hidalgo et al. (2004), reported that birds fed the lowest dietary regimen with a constant ME:CP ratio had increased their FI during the finisher and overall experimental period. Feed intake depression is one of the earliest effects of dietary AA imbalance in broiler chickens (Alam et al., 2014). Also, in this respect, Leung and Rogers (1969) suggest that, this reduction in FI has been indicated to be related with a fall in the most 
limiting AA in the plasma of broiler chickens fed on the imbalance diet. Abd El-Gawad et al. (2004) and Ragab et al. (2012) found that level of CP did not affect FI of the broiler chicks.

Table (3): Effect of dietary protein levels with or without synthetic amino acids and enzyme supplementation on feed intake (FI, g) and feed conversion ratio (FC) of broiler chickens.

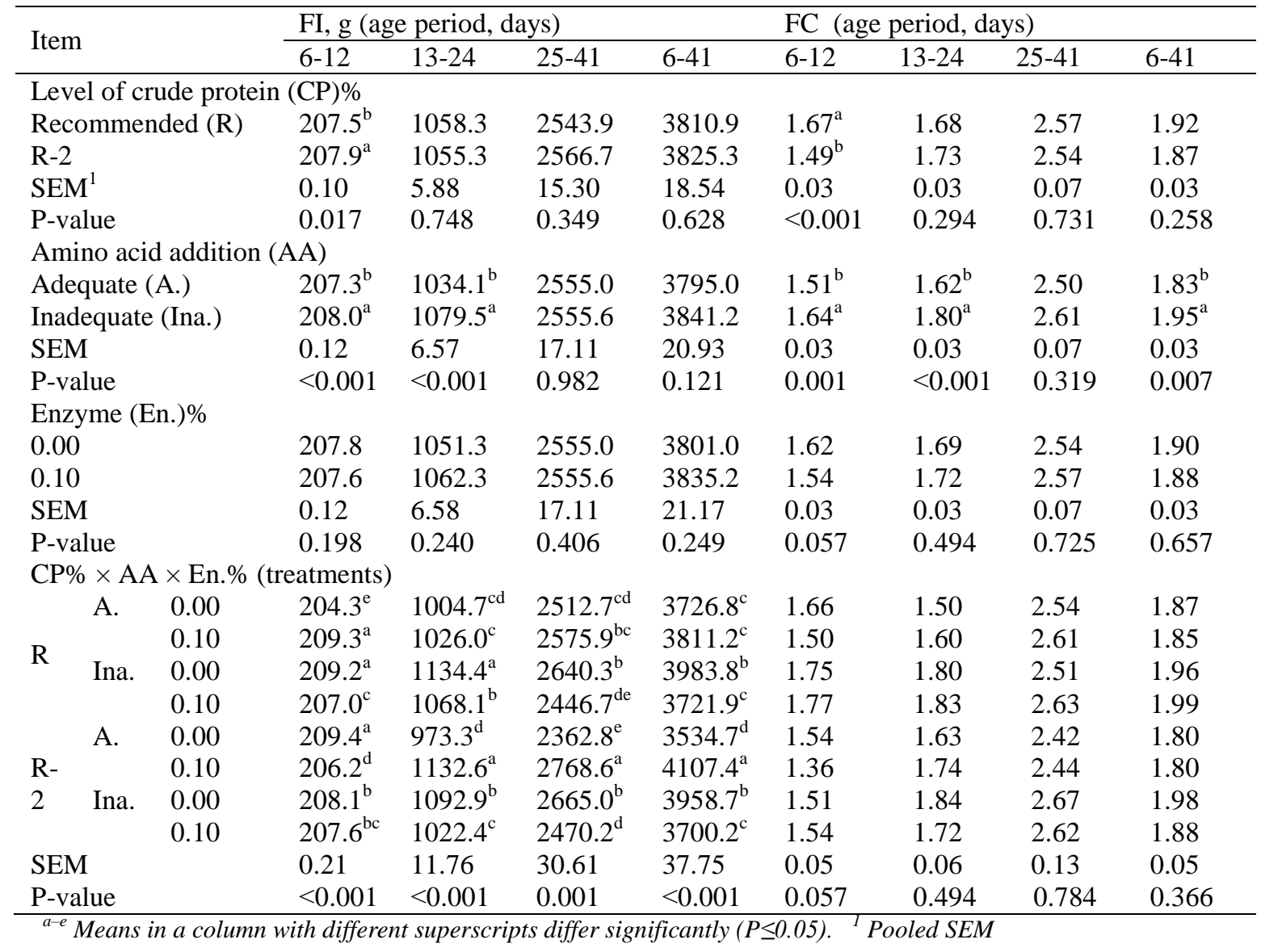

Concerning AA addition, as shown in Table (3), chicks fed diet supplemented with adequate amounts of AA had significantly lower $(\mathrm{P} \leq 0.01)$ FI values during the periods from 6 to 12 and 13 to 24 days. Enzyme supplementation had insignificant effect on FI during all periods studied (Table 3). Data presented in Table (3) indicated that interaction between level of CP, AA and enzyme addition had significant $(\mathrm{P} \leq 0.01)$ effect on FI during all periods studies. Chicks fed diet containing recommended level of CP $-2 \%$ supplemented with AA plus $0.10 \%$ of Avizyme had higher value of FI during finisher and overall experimental periods

Numerically, as shown in Tables (2, 3 and 4), chicks fed diet containing recommended level of CP$2 \%$ supplemented with the requirements of Met. and Ly. plus $0.10 \%$ of Avizyme 1500 had heavier LBW at 41 days of age, higher LBWG, PI and the best FC and CPC values during the period from 6 to 41 days of age, while, those fed diet containing recommended level of CP $-2 \%$ un-supplemented with AA plus $0.10 \%$ of Avizyme had lower values of LBW, LBWG and PI, but differences were not significant (Tables 2, 3 and 4). On the other hand, adequate amounts of AA or Avizyme supplementation to broiler diets enhanced LBW, LBWG, improved FC and PI compared with those fed un-supplemented diet, but differences were not significant (Tables 2, 3 and 4). Recent study by Liu et al. (2017) determined that, the low protein diet decreased $(\mathrm{P}=0.01) \mathrm{LBW}$ as compared with the high protein diet, when the CP level decreased from $22.5 \%$ to $20.5 \%$, there were no effects on FI and FC, but reduced LBWG of broilers at 1 to $21 \mathrm{~d}$ of age. While both the low and high protein diet with multienzyme supplementation increased $(\mathrm{P} \leq 0.01)$ FI and $\mathrm{LBWG}$, with a greater effect in the high $\mathrm{CP}$ diet $(\mathrm{P} \leq 0.001)$, there was no effect of protein or enzymes on FC. In this respect, Ghazi et al. (2003) reported that the use of a mono component 
protease resulted in an increase of LBWG and FI, while FC was either negatively affected or not affected at all, depending on the protease concentration used. Conversely, Hidalgo et al. (2004) found that LBWG and FCR were adversely affected when the broilers were fed diets formulated to contain suboptimum concentrations of CP and ME. Nutritionists can employ protease and synthetic Val. supplementation to achieve additional CP reduction (Vieira et al., 2016).

Table (4): Effect of dietary protein levels with or without synthetic amino acids and enzyme supplementation on crude protein conversion (CPC) and performance index (PI) of broiler chickens.

\begin{tabular}{|c|c|c|c|c|c|c|c|c|c|c|}
\hline \multirow{2}{*}{\multicolumn{3}{|c|}{ Item }} & \multicolumn{4}{|c|}{ CPC (age period, days) } & \multicolumn{4}{|c|}{ PI (age period, days) } \\
\hline & & & $6-12$ & $13-24$ & $25-41$ & $6-41$ & $6-12$ & $13-24$ & $25-41$ & $6-41$ \\
\hline \multicolumn{11}{|c|}{ Level of crude protein $(\mathrm{CP}) \%$} \\
\hline \multicolumn{3}{|c|}{ Recommended (R) } & $0.387^{\mathrm{a}}$ & $0.364^{\mathrm{a}}$ & $0.517^{\mathrm{a}}$ & $0.411^{\mathrm{a}}$ & $16.56^{\mathrm{b}}$ & 56.90 & 81.97 & 54.21 \\
\hline \multicolumn{3}{|c|}{ R-2 } & $0.347^{\mathrm{b}}$ & $0.340^{\mathrm{b}}$ & $0.459^{\mathrm{b}}$ & $0.371^{\mathrm{b}}$ & $19.98^{\mathrm{a}}$ & 54.73 & 81.79 & 54.43 \\
\hline \multicolumn{3}{|c|}{ SEM $^{1}$} & 0.01 & 0.01 & 0.010 & 0.006 & 0.41 & 1.55 & 3.35 & 1.53 \\
\hline \multicolumn{3}{|c|}{ P-value } & $<0.001$ & 0.018 & 0.006 & $<0.001$ & $<0.001$ & 0.337 & 0.971 & 0.924 \\
\hline \multicolumn{11}{|c|}{ Amino acid addition (AA) } \\
\hline \multicolumn{3}{|c|}{ Adequate (A.) } & $0.353^{\mathrm{b}}$ & $0.334^{\mathrm{b}}$ & 0.478 & $0.379^{\mathrm{b}}$ & $19.26^{\mathrm{a}}$ & $60.36^{\mathrm{a}}$ & 86.85 & $57.54^{\mathrm{a}}$ \\
\hline \multicolumn{3}{|c|}{ Inadequate (Ina.) } & $0.381^{\mathrm{a}}$ & $0.371^{\mathrm{a}}$ & 0.497 & $0.404^{\mathrm{a}}$ & $17.28^{\mathrm{b}}$ & $51.28^{\mathrm{b}}$ & 76.90 & $51.11^{\mathrm{b}}$ \\
\hline \multicolumn{3}{|c|}{ SEM } & 0.01 & 0.01 & 0.010 & 0.006 & 0.47 & 1.72 & 3.39 & 1.55 \\
\hline \multicolumn{3}{|c|}{$\mathrm{P}$-value } & 0.002 & $<0.001$ & 0.357 & 0.006 & 0.003 & $<0.001$ & 0.054 & 0.007 \\
\hline \multicolumn{11}{|c|}{ Enzyme (En.)\% } \\
\hline \multicolumn{3}{|c|}{0.00} & 0.375 & 0.348 & 0.484 & 0.394 & $17.61^{\mathrm{b}}$ & 56.19 & 80.26 & 53.17 \\
\hline \multicolumn{3}{|c|}{0.10} & 0.359 & 0.356 & 0.492 & 0.389 & $18.93^{\mathrm{a}}$ & 55.45 & 83.50 & 55.48 \\
\hline \multicolumn{3}{|c|}{ SEM } & 0.01 & 0.01 & 0.010 & 0.006 & 0.46 & 1.72 & 3.39 & 1.55 \\
\hline \multicolumn{3}{|c|}{$\mathrm{P}$-value } & 0.063 & 0.476 & 0.712 & 0.591 & 0.049 & 0.762 & 0.526 & 0.322 \\
\hline \multicolumn{11}{|c|}{$\mathrm{CP} \% \times \mathrm{AA} \times \mathrm{En} . \%$ (treatments) } \\
\hline & \multirow[t]{2}{*}{ A. } & 0.00 & 0.390 & 0.326 & 0.511 & 0.402 & 16.38 & 64.52 & 82.22 & 55.93 \\
\hline \multirow{4}{*}{$\mathrm{R}$} & & 0.10 & 0.345 & 0.348 & 0.524 & 0.395 & 19.19 & 61.97 & 87.42 & 58.60 \\
\hline & \multirow[t]{2}{*}{ Ina. } & 0.00 & 0.400 & 0.389 & 0.505 & 0.420 & 15.42 & 52.29 & 83.10 & 52.32 \\
\hline & & 0.10 & 0.414 & 0.396 & 0.528 & 0.427 & 15.24 & 48.82 & 75.15 & 49.99 \\
\hline & A. & 0.00 & 0.360 & 0.319 & 0.437 & 0.359 & 18.78 & 58.25 & 82.29 & 55.46 \\
\hline \multirow{2}{*}{$\begin{array}{l}\text { R- } \\
2\end{array}$} & & 0.10 & 0.317 & 0.342 & 0.441 & 0.358 & 22.67 & 56.69 & 95.49 & 60.15 \\
\hline & Ina. & 0.00 & 0.353 & 0.361 & 0.483 & 0.394 & 19.86 & 49.69 & 73.42 & 48.95 \\
\hline 2 & & 0.10 & 0.360 & 0.338 & 0.474 & 0.375 & 18.60 & 54.30 & 75.94 & 53.17 \\
\hline \multicolumn{3}{|c|}{ SEM } & 0.01 & 0.01 & 0.030 & 0.010 & 0.85 & 3.04 & 6.07 & 2.77 \\
\hline \multicolumn{3}{|c|}{ P-value } & 0.063 & 0.476 & 0.791 & 0.383 & 0.468 & 0.143 & 0.904 & 0.626 \\
\hline
\end{tabular}

However, Ding et al. (2016), reported that the protease supplementation (300 $\mathrm{mg} / \mathrm{kg}$ ) had no effects on LBWG or FI, while, FC was slightly improved (1.4\%) between 1 and 21 days of age.

Data presented in Tables ( 3 and 4) indicate the main effect of level of CP was significant $(\mathrm{P} \leq 0.01)$ for FC and PI during the period from 6 to 12 days and CPC during all periods studies. Chicks fed diet containing recommended level of $\mathrm{CP}$ had the worst FC and the lower PI value during the period 6 to 12 days, and those fed R-2\% CP had the best FC and the higher value of PI during the same period. Also, chicks fed diet containing recommended level of $\mathrm{CP}$ had the worst $\mathrm{CPC}$ during all periods studies. It can be concluded that $\mathrm{CP}$ can be reduced from the recommended level by $2 \%$ without affecting LBW, LBWG, FI, FC and PI (Tables 2, 3 and 4).

In this regard, Aletor et al. (2000) suggest that, protein efficiency ratio were generally significantly improved with decreasing dietary CP. In contrast to previous reports from our results Ragab et al. (2012) found that chicks fed diets containing recommended level of CP had the best FC and CPC during the over all period studied, while, feeding the sub-optimal CP level diet resulted in the worst FC and CPC values during the same period.

Concerning AA addition, data presented in Tables (3 and 4) indicate the main effects of AA addition significantly affected FC, CPC and PI during all periods studied, except, the finisher period which was 
insignificantly $(\mathrm{P} \geq 0.05)$ affected. The results cleared that chicks fed adequate amounts of AA supplement diets recorded significantly $(\mathrm{P} \leq 0.01)$ the best values of FC, CPC (this may be partially attributed to lower FI of AA supplemented groups) and the higher PI during all periods studies (Tables 3 and 4).

2- Blood constituents: Impact of $\mathrm{CP}, \mathrm{AA}$ and enzyme supplementation on blood constituents of Ross broiler chicks are presented in Table (5). The results indicated no significant differences due to level of $\mathrm{CP}$ and AA addition on blood constituents, except, red blood cells count (RBCs) which was significantly $(\mathrm{P} \leq 0.05)$ affected. Chicks fed R-2\% CP had higher value of RBCs, while, chicks fed R had lower value and chicks fed diet containing inadequate amounts of AA had higher value of RBCs, while, chicks fed adequate amounts of AA had lower value at the end of the experiment. Enzyme addition had insignificantly affected blood constituents. The results indicated no significant differences due to interaction effect of dietary treatments on blood constituents, except, neutrophils\% (segment) which was significantly $(\mathrm{P} \leq 0.05)$ affected (Table 5). Chicks fed control diet had higher value of segment while, chicks fed diet containing R-2\% supplemented with the requirements of Met. and Ly. plus $0.10 \%$ of Avizyme had lower value of segment at the end of the experiment (Table 5). Similar results were previously observed by Ragab et al. (2012) who found that chicks fed diet containing suboptimal CP level unsupplemented with organic acids had higher RBCs value.

Table (5): Effect of dietary protein levels with or without synthetic amino acids and enzyme supplementation on some blood parameters of broiler chickens.

\begin{tabular}{|c|c|c|c|c|c|c|c|c|c|c|c|}
\hline \multirow{2}{*}{\multicolumn{2}{|c|}{ Item }} & \multirow{2}{*}{$\begin{array}{c}\text { Hemog } \\
\text { lobin } \\
\text { (g/dL) }\end{array}$} & \multirow{2}{*}{$\begin{array}{c}\text { Hemat } \\
\text { ocrit } \\
\text { (Ht) } \%\end{array}$} & \multirow{2}{*}{$\begin{array}{c}\text { Red } \\
\text { blood } \\
\text { cells } \\
\text { (RBCs } \\
\text { ) }\end{array}$} & \multirow{2}{*}{$\begin{array}{c}\text { Mean } \\
\text { Cell } \\
\text { Volum } \\
\text { e } \\
\text { (MCV } \\
\mu 3) \\
\end{array}$} & \multirow{2}{*}{$\begin{array}{c}\text { Total } \\
\text { leucoc } \\
\text { ytes } \\
\text { (TLC)/ } \\
\text { cmm }\end{array}$} & \multirow{2}{*}{$\begin{array}{c}\text { Lymp } \\
\text { hocyte } \\
\text { (LYM } \\
\text { P\%) }\end{array}$} & \multicolumn{2}{|c|}{ Neutrophils\% } & \multirow{2}{*}{$\begin{array}{c}\text { Eosino } \\
\text { phils } \\
\text { (ESIN } \\
\text { O\%) }\end{array}$} & \multirow{2}{*}{$\begin{array}{c}\text { Basophil } \\
\text { s } \\
\text { (BASO } \\
\% \text { ) }\end{array}$} \\
\hline & & & & & & & & $\begin{array}{c}\text { SEGME } \\
\text { NT }\end{array}$ & $\begin{array}{c}\text { STAF } \\
\text { F }\end{array}$ & & \\
\hline \multicolumn{12}{|c|}{ Level of crude protein (CP) \% } \\
\hline \multicolumn{2}{|c|}{$\begin{array}{l}\text { Recommended } \\
\text { (R) }\end{array}$} & 10.77 & 35.82 & $2.83^{b}$ & 138.48 & 137.92 & 54.437 & 41.44 & 1.688 & 2.375 & 0.063 \\
\hline \multicolumn{2}{|c|}{ R-2 } & 10.60 & 34.79 & $3.05^{\mathrm{a}}$ & 137.33 & 133.53 & 60.042 & 35.21 & 2.042 & 2.500 & 0.208 \\
\hline \multicolumn{2}{|l|}{ SEM $^{1}$} & 0.20 & 0.58 & 0.05 & 1.91 & 3.79 & 2.890 & 2.450 & 0.290 & 0.520 & 0.130 \\
\hline \multicolumn{2}{|l|}{ P-value } & 0.552 & 0.248 & 0.019 & 0.691 & 0.446 & 0.211 & 0.109 & 0.416 & 0.873 & 0.445 \\
\hline \multicolumn{12}{|c|}{ Amino acid addition (AA) } \\
\hline \multicolumn{2}{|c|}{ Adequate (A.) } & 10.52 & 35.07 & $2.82^{b}$ & 137.35 & 132.92 & $\mathbf{5 3 . 5 6 2}$ & 41.81 & 1.938 & 2.500 & 0.188 \\
\hline \multicolumn{2}{|c|}{$\begin{array}{l}\text { Inadequate } \\
\text { (Ina.) }\end{array}$} & 10.85 & 35.54 & $3.05^{\mathrm{a}}$ & 138.46 & 138.94 & 60.917 & 34.83 & 1.792 & 2.375 & 0.083 \\
\hline \multicolumn{2}{|c|}{ SEM } & 0.20 & 0.58 & 0.05 & 1.91 & 3.79 & 2.890 & 2.450 & 0.290 & 0.520 & 0.130 \\
\hline \multicolumn{2}{|l|}{ P-value } & \multicolumn{10}{|c|}{ Enzyme (En.)\% } \\
\hline \multicolumn{2}{|l|}{0.00} & 10.65 & 35.17 & 2.96 & 137.69 & 137.18 & 54.938 & 40.81 & 1.813 & 2.250 & 0.188 \\
\hline \multicolumn{2}{|l|}{0.10} & 10.72 & 35.44 & 2.92 & 138.13 & 134.26 & 59.542 & 35.83 & 1.917 & 2.625 & 0.083 \\
\hline \multicolumn{2}{|l|}{ SEM } & 0.20 & 0.61 & 0.06 & 1.96 & 3.99 & 3.040 & 2.580 & 0.300 & 0.550 & 0.130 \\
\hline \multicolumn{2}{|l|}{$P$-value } & 0.819 & 0.755 & 0.624 & 0.879 & 0.610 & 0.299 & 0.192 & 0.808 & 0.633 & 0.583 \\
\hline \multicolumn{12}{|c|}{$\mathbf{C P} \% \times \mathbf{A A} \times \mathbf{E n} . \%$ (treatments) } \\
\hline A. & 0.00 & 10.55 & 35.53 & 2.69 & 138.75 & 139.13 & 44.750 & $51.75^{\mathrm{a}}$ & 1.750 & 1.500 & 0.250 \\
\hline \multirow{3}{*}{ R Ina. } & 0.10 & 10.43 & 35.48 & 2.52 & 140.67 & 136.80 & 44.000 & $51.00^{\mathrm{ab}}$ & 2.000 & 3.000 & $\mathbf{0 . 0 0 0}$ \\
\hline & $\mathbf{0 . 0 0}$ & 11.40 & 37.20 & 3.06 & 138.50 & 136.35 & 60.000 & $37.50^{\text {abcd }}$ & 1.000 & 1.500 & 0.000 \\
\hline & 0.10 & 10.70 & 35.10 & 3.05 & 136.00 & 139.40 & 69.000 & $25.50^{\mathrm{cd}}$ & 2.000 & 3.500 & 0.000 \\
\hline \multirow{2}{*}{$\mathbf{R}^{\mathrm{A} .}$} & 0.00 & 10.20 & 33.60 & 3.04 & 132.50 & 135.15 & 54.000 & $40.00^{\mathrm{abcd}}$ & 2.000 & 3.500 & 0.500 \\
\hline & 0.10 & 10.90 & 35.70 & 3.05 & 137.50 & 118.95 & 71.500 & $24.50^{d}$ & 2.000 & 2.000 & 0.000 \\
\hline \multirow{2}{*}{ - Ina. } & 0.00 & 10.45 & 34.35 & 3.04 & 141.00 & 138.10 & 61.000 & $34.00^{\text {bcd }}$ & 2.500 & 2.500 & 0.000 \\
\hline & 0.10 & 10.83 & 35.50 & 3.05 & 138.33 & 141.90 & $\mathbf{5 3 . 6 6 7}$ & $42.33^{\mathrm{abc}}$ & 1.667 & 2.000 & 0.333 \\
\hline SEM & & 0.31 & 1.01 & 1.00 & 3.04 & 6.03 & 4.590 & 3.900 & 0.460 & 0.830 & 0.200 \\
\hline$P$-value & & 0.819 & 0.755 & 0.621 & 0.777 & 0.524 & 0.064 & 0.031 & 0.365 & 0.873 & 0.445 \\
\hline
\end{tabular}

3-Slaughter parameters\%: Impact of CP, AA and enzyme supplementation on slaughter parameters\% of Ross broiler chicks are presented in Table (6). Neither level of CP and enzyme addition nor interaction between level of CP, AA and enzyme addition had any significant effect on slaughter parameters\% at the end of the finishing period (Table 6). It may be mentioned that perhaps the carcass weight and breast meat weight were not affected due to adequate levels of essential AA particularly Lys. and Met. in low $\mathrm{CP}$ diets, because these two AA are exclusively used for protein accretion in the body (Si et al., 2001 and Baker et al., 2002). 
Table (6): Effect of dietary protein levels with or without synthetic amino acids and enzyme supplementation on slaughter parameters\% of broiler chickens.

\begin{tabular}{|c|c|c|c|c|c|c|c|c|c|c|c|c|c|}
\hline \multirow{2}{*}{\multicolumn{2}{|c|}{ Item }} & \multirow[b]{2}{*}{$\begin{array}{l}\text { Live } \\
\text { body } \\
\text { weight } \\
\text { (g) }\end{array}$} & \multirow[b]{2}{*}{$\begin{array}{c}\text { Blood } \\
\text { \&feath } \\
\text { er }\end{array}$} & \multirow[b]{2}{*}{$\begin{array}{c}\text { Total } \\
\text { giblets }\end{array}$} & \multirow[b]{2}{*}{$\begin{array}{l}\text { Abd } \\
\text { omin } \\
\text { al } \\
\text { fat }\end{array}$} & \multirow[b]{2}{*}{$\begin{array}{c}\text { Half } \\
\text { breast }\end{array}$} & \multirow[b]{2}{*}{$\begin{array}{l}\text { Half } \\
\text { rear }\end{array}$} & \multirow[b]{2}{*}{$\begin{array}{c}\text { Breas } \\
\mathbf{t} \\
\text { meat }\end{array}$} & \multirow{2}{*}{\multicolumn{2}{|c|}{$\begin{array}{c}\text { Carcas } \\
\text { s } \\
\text { weight } \\
\text { after } \\
\text { eviscer } \\
\text { ation } \\
\end{array}$}} & \multirow[b]{2}{*}{$\begin{array}{c}\text { Dressi } \\
\text { ng }\end{array}$} & \multicolumn{2}{|c|}{ Tibia } \\
\hline & & & & & & & & & & & & $\begin{array}{c}\text { Weigh } \\
\mathbf{t}\end{array}$ & Ash \\
\hline \multicolumn{14}{|c|}{ Level of crude protein (CP) \% } \\
\hline \multicolumn{2}{|c|}{$\begin{array}{l}\text { Recommended } \\
\text { (R) }\end{array}$} & 1962.2 & 9.27 & 5.04 & 1.80 & 17.49 & 13.5 & 88.22 & 85.29 & 62.77 & 67.80 & 0.236 & 46.03 \\
\hline \multicolumn{2}{|l|}{ R-2 } & 1982.4 & 8.66 & 4.76 & 2.07 & 17.16 & 14.5 & 87.13 & 86.59 & 63.03 & 67.79 & 0.247 & 46.22 \\
\hline \multicolumn{2}{|l|}{ SEM $^{1}$} & 71.03 & 0.45 & 0.17 & 0.22 & 0.28 & 0.30 & 0.47 & 0.84 & 0.66 & 0.62 & 0.010 & 0.75 \\
\hline \multicolumn{2}{|l|}{ P-value } & 0.850 & 0.372 & 0.279 & 0.42 & 0.438 & 0.05 & 0.141 & 0.314 & 0.792 & 0.986 & 0.474 & 0.862 \\
\hline \multicolumn{14}{|c|}{ Amino acid addition (AA) } \\
\hline \multirow{2}{*}{\multicolumn{2}{|c|}{$\begin{array}{l}\text { Adequate (A.) } \\
\text { Inadequate } \\
\text { (Ina.) }\end{array}$}} & 2036.9 & 8.27 & 4.76 & 1.89 & $17.87^{\mathrm{a}}$ & 13.97 & 88.40 & 86.34 & $64.09^{\mathrm{a}}$ & $68.84^{\mathrm{a}}$ & 0.234 & 46.40 \\
\hline & & 1907.6 & 9.65 & 5.04 & 1.98 & $16.79^{b}$ & 14.09 & 86.94 & 85.54 & $61.71^{b}$ & $66.75^{b}$ & 0.249 & 45.48 \\
\hline & 71.03 & 0.45 & 0.17 & 0.22 & 0.28 & 0.30 & 0.47 & 0.84 & 0.66 & 0.62 & 0.010 & 0.75 \\
\hline \multicolumn{2}{|l|}{$P$-value } & 0.242 & 0.063 & 0.278 & $\begin{array}{l}0.78 \\
1\end{array}$ & 0.025 & 0.795 & 0.058 & 0.531 & 0.034 & 0.044 & 0.311 & 0.621 \\
\hline \multicolumn{14}{|c|}{ Enzyme (En.)\% } \\
\hline \multicolumn{2}{|c|}{0.00} & 1967.2 & 8.32 & 5.01 & 1.88 & 17.43 & 14.14 & 87.75 & 85.97 & 63.58 & 68.59 & 0.243 & 45.78 \\
\hline \multicolumn{2}{|l|}{0.10} & 1977.3 & 9.61 & 4.79 & 1.99 & 17.23 & 13.93 & 87.60 & 85.91 & 62.21 & 67.00 & 0.240 & 46.48 \\
\hline \multicolumn{2}{|l|}{ SEM } & 71.03 & 0.45 & 0.17 & 0.22 & 0.28 & 0.30 & 0.47 & 0.84 & 0.66 & 0.62 & 0.010 & 0.75 \\
\hline \multicolumn{2}{|l|}{ P-value } & 0.924 & 0.078 & 0.380 & 0.72 & 0.631 & 0.65 & 0.835 & 0.959 & 0.187 & 0.111 & 0.835 & 0.534 \\
\hline \multicolumn{14}{|c|}{$\mathbf{C P} \% \times \mathbf{A A} \times \mathbf{E n} . \%$ (treatments) } \\
\hline A. & 0.00 & 1965.8 & 7.83 & 5.06 & 1.51 & 17.36 & 14.34 & 87.73 & 86.79 & 64.71 & 69.77 & 0.243 & 47.33 \\
\hline \multirow{3}{*}{$\mathbf{R}$ Ina. } & 0.10 & 2052.9 & 8.24 & 4.74 & 1.88 & 18.31 & 12.98 & 88.99 & 85.50 & 63.75 & 68.50 & 0.221 & 46.21 \\
\hline & $\mathbf{0 . 0 0}$ & 2025.0 & 9.12 & 5.34 & 1.61 & 17.71 & 13.89 & 88.95 & 85.52 & 63.15 & 68.49 & 0.224 & 45.71 \\
\hline & 0.10 & 1805.0 & 11.89 & 5.00 & 2.19 & 16.60 & 12.96 & 87.20 & 83.37 & 59.45 & 64.46 & 0.256 & 44.87 \\
\hline R A. & 0.00 & 1945.0 & 7.64 & 4.84 & 2.29 & 18.11 & 14.07 & 87.90 & 85.74 & 64.16 & 69.00 & 0.237 & 45.36 \\
\hline $\mathbf{K}$ & 0.10 & 2184.0 & 9.38 & 4.39 & 1.88 & 17.69 & 14.49 & 88.99 & 87.33 & 63.72 & 68.10 & 0.234 & 46.72 \\
\hline Ina. & 0.00 & 1933.0 & 8.69 & 4.80 & 2.09 & 16.54 & 14.24 & 86.40 & 85.85 & 62.32 & 67.11 & 0.267 & 44.70 \\
\hline & 0.10 & 1867.5 & 8.91 & 5.01 & 2.02 & 16.31 & 15.28 & 85.22 & 87.44 & 61.92 & 66.93 & 0.248 & 48.12 \\
\hline SEM & & 107.39 & 0.68 & 0.25 & 0.33 & 0.42 & 0.46 & 0.71 & 1.27 & 1.00 & 0.94 & 0.014 & 1.13 \\
\hline P-value & & 0.955 & 0.172 & 0.492 & 0.92 & 0.201 & 0.92 & 0.787 & 0.864 & 0.490 & 0.364 & 0.233 & 0.692 \\
\hline
\end{tabular}

In the studies of Kerr and Kidd (1999) suggest that abdominal fat\% was unaffected when dietary CP levels were reduced by $2 \%$. Moreover, decreasing dietary CP from 22.5 to $15.3 \%$ has no significant influence on liver, total body protein content and abdominal fat, conversely, total body fat content was increased significantly $(\mathrm{P} \leq 0.01)$ by $51 \%$ (Aletor et al., 2000). Also, Abd El-Gawad et al. (2004) and Nawaz et al. (2006) found that there were no significant differences in carcass characteristics or abdominal fat weight in broilers fed low CP diets. In addition, no differences in carcass weight, breast meat weight and abdominal fat (Hidalgo et al.,2004 and Kamran et al.,2008) thigh weight, liver and heart weights (Kamran et al., 2008) in broilers fed low CP diets with a constant ME:CP ratio. But, Dozier and Moran (2002) reported that feeding broiler chickens diet formulated to contain suboptimum level of CP and ME impaired the amount and yields of carcass parts. Si et al. (2004) reported significant increase in abdominal fat with decrease in the dietary $\mathrm{CP}$ level. Carcass composition becomes inferior in broilers fed diets in which $\mathrm{CP}$ has been lowered by more than $3 \%$, even when all known nutrient requirements are met (Sterling et al., 2005 and Waldroup et al., 2005).

Concerning AA addition, the results indicated that no significant differences due to AA on slaughter parameters\%, except, half breast, carcass weight after evisceration and dressing which were significantly $(\mathrm{P} \leq 0.05)$ affected (Table 6). It can be concluded that, chicks fed diet containing adequate amounts of AA had higher values of half breast, carcass weight after evisceration and dressing\%, while, chicks fed inadequate amounts of AA had lower values at the end of experiment. The carcass composition responses were similar to that of LBW and LBWG, which emphasis this conclusion, no obvious increase in abdominal fat content was recorded. However, Swennen et al. (2006) as a consequence of enhanced de novo lipogenesis in the liver of birds fed the low CP diets, birds are expected to have increased liver weights and deposit more abdominal fat due to increased ME:CP ratio. In this regard, Lipstein and Bornstein (1975) showed that the effect of dietary CP on carcass composition is basically an AA effect. Similarly increasing dietary Met. levels have shown to reduce abdominal fat content (Mendonca and 
Jensen, 1989) and increase breast meat yield (Hilckling et al., 1990). Also, Holsheimer and Veerkamp (1992) demonstrated that dietary Lys. content resulted in an increase of breast meat yield. These results are in harmony with those obtained by Waldroup et al. (2006) who reported that reduction of more than $0.10 \%$ Met from current values have shown to negatively affected breast meat yield in a linear manner. Similar results were reported by Zaman et al. (2008) who concluded that lowering the dietary CP with EAA supplementation resulted in breast meat yield similar to those birds fed on control diet. It seems that low CP slightly increased the digestibility of AA required for carcass formation.

4- Tibia parameters: Data presented in Table (6) showed that neither level of CP, AA and enzyme addition nor interaction between level of $\mathrm{CP}, \mathrm{AA}$ and enzyme addition had any significant effect on tibia weight and ash\% at the end of the finishing period. This finding disagreed with Ragab et al. (2012) who found that the highest ash $(\mathrm{P} \leq 0.01)$ value was observed for chicks fed diets containing optimal $\mathrm{CP}$ level, while, those fed diet containing suboptimal level of $\mathrm{CP}$ had significantly lower value.

5- Chemical composition of broiler meat: Level of CP, AA and interaction between level of CP, AA and enzyme addition (experimental treatments) had insignificantly affected chemical composition of broiler meat (Table 7). Inclusion of enzyme in broiler diet at $0.1 \%$ caused a significant $(\mathrm{P} \leq 0.01)$ increase in moisture\% of broiler meat. Carcass part significantly influenced $(\mathrm{P} \leq 0.01)$ chemical composition of broiler meat except, ash and NFE\% which was insignificantly affected. Rear part had higher fat\% than the breast part (5.89 vs. $0.82 \%$ ). However, breast part had higher moisture and protein\% (consequently lower fat \%) than rear part (Table 7).

These results agree with the those of Neto et al. (2000) who reported that chicks fed low CP diets supplemented with EAAs had similar total carcass protein contents as those fed a $24 \%$ dietary CP. By contrast, Zaman et al. (2008) reported that increases in dietary CP resulted in increased dry matter, CP and fat contents of carcass. Also, Si et al. (2001) demonstrated that the CP and AA status of a diet influences the carcass composition of broilers and decrease in dietary CP causes a decrease in carcass protein and an increase in carcass fat content. Moreover, Ragab et al. (2012) reported that level of CP significantly affected protein, fat and ash of chicks meat. The highest fat\% (the lowest protein and ash\%) were observed for chicks fed diets containing sub-optimal CP level, while those fed diet containing recommended level of $\mathrm{CP}$ had lower fat\% (the highest protein and ash\%), however, insignificantly affected moisture and NFE\% (Ragab et al., 2012). The inverse relationship found between moisture\% and fat\% values obtained in the present study is in agreement with that reported by Marks (1993) and Ragab et al. (2012) in chemical composition of Japanese quail meat and broiler chicks.

Generally, the discrepancies in responses often observed in the researches in chicks fed protein AA supplemented diets can be partly attributed to other factors. Such as the degree of CP restriction, the inclusion of the $\mathrm{CP}$ and $\mathrm{ME}$ contributions of the AA supplements, diets composition, the class (or strain) and age of the chickens used and rearing conditions, whether or AA imbalances. Also perhaps differences in experimental designs could be responsible for the variations observed.

\section{6- Economical efficiency (EEf):}

Results in Table 8 show that EEf values during the period from 6 to 41 days of age was improved of chicks fed diet containing R-2\% supplemented with the requirements of Met. and Ly. plus $0.10 \%$ of Avizyme had the best economical and relative efficiency values being 0.2928 and $129.92 \%$, respectively followed by chicks fed control diet $-2 \%$ CP supplemented with the requirements of Met. and Ly. plus $0.00 \%$ of Avizyme $(0.2617$ and $116.11 \%$, respectively) then chicks fed control diet supplemented with $0.1 \%$ Avizyme ( 0.2345 and $104.04 \%$, respectively) as compared with those fed the control diet and other treatments. Whereas, chicks fed control diet $-2 \% \mathrm{CP}$ inadequate amounts of AA plus $0.00 \%$ of Avizyme had the lowest corresponding values, being 0.1811 and $80.36 \%$, respectively). The relative efficiency varied between $80.36 \%$, to $129.92 \%$, which is of minor importance relative to other factors of production. In this respect, Vieira et al. (2016) stated that feeds formulated with reduced CP are less expensive. The results of this study are disagreement with those of Abd El-Gawad et al. (2004) and Ragab et al. (2012) who found that broiler chicks fed diets containing either optimum level of CP or adding probiotics, EEf values were increased. 
Table (7): Effect of dietary protein levels with or without synthetic amino acids and enzyme supplementation on chemical composition of broiler meat $\%$.

\begin{tabular}{|c|c|c|c|c|c|c|c|}
\hline Item & \multicolumn{3}{|c|}{ Moisture } & Protein & Fat & Ash & NFE \\
\hline \multicolumn{8}{|c|}{ Level of crude protein $(\mathrm{CP}) \%$} \\
\hline Recommended (R) & \multicolumn{3}{|l|}{74.52} & 18.78 & 3.18 & 2.29 & 1.23 \\
\hline $\mathrm{R}-2$ & \multicolumn{3}{|l|}{74.48} & 18.71 & 3.53 & 2.05 & 1.23 \\
\hline SEM $^{1}$ & \multicolumn{3}{|l|}{0.26} & 0.63 & 0.75 & 0.17 & 0.01 \\
\hline P-value & \multicolumn{3}{|l|}{0.908} & 0.942 & 0.745 & 0.322 & 0.938 \\
\hline \multicolumn{8}{|c|}{ Amino acid addition (AA) } \\
\hline Adequate (A.) & \multicolumn{3}{|l|}{74.49} & 18.89 & 3.08 & 2.31 & 1.23 \\
\hline Inadequate (Ina.) & \multicolumn{3}{|l|}{74.51} & 18.60 & 3.63 & 2.03 & 1.23 \\
\hline SEM & \multicolumn{3}{|l|}{0.26} & 0.63 & 0.75 & 0.17 & 0.01 \\
\hline P-value & \multicolumn{3}{|l|}{0.951} & 0.747 & 0.612 & 0.251 & 0.817 \\
\hline \multicolumn{8}{|l|}{ Enzyme (En.)\% } \\
\hline 0.00 & \multicolumn{3}{|l|}{$73.95^{\mathrm{b}}$} & 18.75 & 3.72 & 2.35 & 1.23 \\
\hline 0.10 & \multicolumn{3}{|c|}{$75.05^{\mathrm{a}}$} & 18.74 & 2.99 & 1.99 & 1.23 \\
\hline SEM & \multicolumn{3}{|l|}{0.26} & 0.63 & 0.75 & 0.17 & 0.01 \\
\hline P-value & \multicolumn{3}{|l|}{0.006} & 0.988 & 0.499 & 0.132 & 0.817 \\
\hline \multicolumn{8}{|l|}{ Carcasse part } \\
\hline Breast & \multicolumn{3}{|c|}{$75.09^{\mathrm{a}}$} & $20.79^{\mathrm{a}}$ & $0.82^{\mathrm{b}}$ & 2.07 & 1.24 \\
\hline Rear & \multicolumn{3}{|c|}{$73.91^{\mathrm{b}}$} & $16.70^{\mathrm{b}}$ & $5.89^{\mathrm{a}}$ & 2.28 & 1.22 \\
\hline SEM & \multicolumn{3}{|l|}{0.30} & 0.21 & 0.20 & 0.19 & 0.01 \\
\hline P-value & \multicolumn{3}{|l|}{0.009} & $<0.001$ & $<0.001$ & 0.438 & 0.070 \\
\hline \multicolumn{8}{|c|}{$\mathrm{CP} \% \times \mathrm{AA} \times \mathrm{En} . \%$ (treatments) } \\
\hline \multirow{4}{*}{$\mathrm{R}$} & A. & 0.00 & 72.65 & 19.38 & 3.97 & 2.77 & 1.23 \\
\hline & & 0.10 & 75.15 & 18.49 & 2.38 & 2.75 & 1.24 \\
\hline & \multirow[t]{2}{*}{ Ina. } & 0.00 & 75.12 & 18.32 & 3.27 & 2.05 & 1.23 \\
\hline & & 0.10 & 75.16 & 18.93 & 3.10 & 1.59 & 1.22 \\
\hline \multirow{4}{*}{$\mathrm{R}-2$} & \multirow[t]{2}{*}{ A. } & 0.00 & 74.54 & 19.04 & 3.18 & 2.00 & 1.23 \\
\hline & & 0.10 & 75.61 & 18.65 & 2.80 & 1.72 & 1.22 \\
\hline & \multirow[t]{2}{*}{ Ina. } & 0.00 & 73.46 & 18.27 & 4.44 & 2.60 & 1.23 \\
\hline & & 0.10 & 74.30 & 18.89 & 3.69 & 1.89 & 1.23 \\
\hline SEM & 0.52 & & & 1.26 & 1.49 & 0.33 & 0.01 \\
\hline P-value & 0.138 & & & 0.891 & 0.674 & 0.991 & 0.321 \\
\hline
\end{tabular}


Table (8): Effect of dietary protein levels with or without synthetic amino acids and enzyme supplementation on economical efficiency (EEf) of broiler chickens.

\begin{tabular}{|c|c|c|c|c|c|c|c|c|}
\hline \multirow{3}{*}{$\begin{array}{l}\text { Item } \\
\text { Amino acid addition }\end{array}$} & \multicolumn{8}{|c|}{ Level of crude protein $\%$} \\
\hline & \multicolumn{4}{|c|}{ Recommended } & \multicolumn{4}{|c|}{ Recommended -2} \\
\hline & \multicolumn{2}{|c|}{ Accurate } & \multicolumn{2}{|c|}{ Inaccurate } & \multicolumn{2}{|c|}{ Accurate } & \multicolumn{2}{|c|}{ Inaccurate } \\
\hline Enzyme \% & 0.00 & 0.10 & 0.00 & 0.10 & 0.00 & 0.10 & 0.00 & 0.10 \\
\hline$a_{1}$ & 0.2043 & 0.2093 & 0.2092 & 0.2070 & 0.2094 & 0.2062 & 0.2081 & 0.2076 \\
\hline $\mathrm{b}_{1}$ & 622.93 & 627.93 & 617.11 & 622.11 & 593.55 & 598.55 & 584.35 & 589.35 \\
\hline$a_{1} \times b_{1}=c_{1}$ & 127.26 & 131.43 & 129.10 & 128.78 & 124.29 & 123.42 & 121.60 & 122.35 \\
\hline $\mathrm{a}_{2}$ & 1.0047 & 1.0260 & 1.1344 & 1.0681 & 0.9733 & 1.1326 & 1.0929 & 1.0224 \\
\hline $\mathrm{b}_{2}$ & 617.29 & 622.29 & 611.49 & 616.49 & 589.30 & 594.30 & 580.10 & 585.10 \\
\hline $\mathrm{a}_{2} \times \mathrm{b}_{2}=\mathrm{c}_{2}$ & 620.19 & 638.47 & 693.67 & 658.47 & 573.57 & 673.10 & 633.99 & 598.21 \\
\hline$a_{3}$ & 2.5127 & 2.5759 & 2.6403 & 2.4467 & 2.3628 & 2.7686 & 2.6650 & 2.4702 \\
\hline $\mathrm{b}_{3}$ & 596.64 & 601.64 & 595.08 & 600.08 & 567.69 & 572.69 & 562.83 & 567.83 \\
\hline$a_{3} \times b_{3}=c_{3}$ & 1499.2 & 1549.8 & 1571.2 & 1468.2 & 1341.3 & 1585.5 & 1499.9 & 1402.7 \\
\hline$\left(c_{1}+c_{2}+c_{3}\right)=c_{\text {total }}$ & 2246.6 & 2319.7 & 2394.0 & 2255.5 & 2039.2 & 2382.1 & 2255.5 & 2123.2 \\
\hline $\mathrm{D}$ & 1497.8 & 1497.8 & 1497.8 & 1497.8 & 1497.8 & 1497.8 & 1497.8 & 1497.8 \\
\hline $\mathrm{e}=\mathrm{c}_{\text {total }}+\mathrm{d}$ & 3744.4 & 3817.4 & 3891.7 & 3753.2 & 3536.9 & 3879.8 & 3753.3 & 3621.0 \\
\hline $\mathrm{F}$ & 1.9949 & 2.0489 & 2.0204 & 1.9509 & 1.9402 & 2.1808 & 1.9274 & 1.9261 \\
\hline G & 2300.0 & 2300.0 & 2300.0 & 2300.0 & 2300.0 & 2300.0 & 2300.0 & 2300.0 \\
\hline$f \times g=h$ & 4588.3 & 4712.5 & 4646.9 & 4487.1 & 4462.5 & 5015.8 & 4433.0 & 4430.0 \\
\hline $\mathrm{h}-\mathrm{e}=\mathrm{i}$ & 843.88 & 895.05 & 755.20 & 733.85 & 925.51 & 1136.0 & 679.73 & 809.07 \\
\hline $\mathrm{EEf}=\mathrm{i} / \mathrm{e}$ & 0.2254 & 0.2345 & 0.1941 & 0.1955 & 0.2617 & 0.2928 & 0.1811 & 0.2234 \\
\hline $\mathrm{R}$ & 100.00 & 104.04 & 86.10 & 86.757 & 116.11 & 129.92 & 80.36 & 99.142 \\
\hline \multicolumn{9}{|c|}{$\begin{array}{l}a_{1}, a_{2} \text { and } a_{3} \ldots \ldots . . . . . . . . . . . \text { average feed intake (Kg/bird) during the periods of starter, grower and finisher, } \\
\text { respectively. }\end{array}$} \\
\hline \multicolumn{9}{|c|}{$\begin{array}{l}b_{1}, b_{2} \text { and } b_{3} \ldots \ldots \ldots \ldots \ldots \ldots \text { price / Kg feed (P.T.) during the periods of starter, grower and finisher, respectively } \\
\text { (based on average local market price of diets during the experimental time). }\end{array}$} \\
\hline \multicolumn{9}{|c|}{$c_{1,} c_{2}$ and $c_{3} \ldots \ldots \ldots \ldots \ldots \ldots$ feed cost (P.T.) during the periods of starter, grower and finisher, respectively. } \\
\hline \multicolumn{9}{|c|}{ Total feed cost $(P . T)=.c_{\text {total }}=\left(c_{1}+c_{2}+c_{3}\right)$} \\
\hline \multicolumn{9}{|l|}{$d \ldots \ldots \ldots . . . .$. other costs } \\
\hline \multicolumn{9}{|l|}{ Total cost $=c_{\text {total }}+d=e$} \\
\hline \multicolumn{9}{|c|}{ Average $L B W G(K g /$ bird $) \quad f$} \\
\hline \multicolumn{9}{|c|}{ 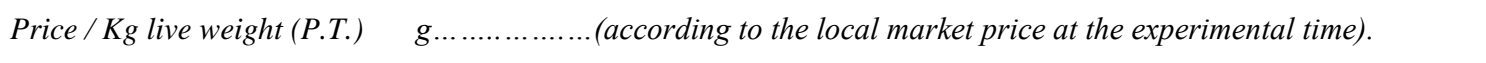 } \\
\hline \multicolumn{9}{|c|}{ Total revenue $(P . T)=.f x g=h$} \\
\hline \multicolumn{9}{|c|}{ Net revenue $($ P.T. $)=h-e=i$} \\
\hline \multicolumn{9}{|c|}{ Economical efficiency $=(i / e) \ldots \ldots \ldots \ldots \ldots \ldots . . . .($ net revenue per unit feed cost $)$. } \\
\hline $\begin{array}{l}\text { Relative efficiency } \\
\text { 100). }\end{array}$ & $r \ldots$ & $\ldots \ldots \ldots .(c$ & suming $t$ & t econor & cal efficie & of the & ntrol gr & (1) equals \\
\hline
\end{tabular}




\section{Emam}

In general, the optimum performance in the present experiment was obtained by broilers fed diets formulated to contain 21.38, 19.63, and $18.08 \%$ CP supplemented with Met. and Ly. for starter, grower and finisher periods, respectively.

\section{CONCLUSIONS}

The results of the present study indicated that Ross broiler chicks fed low CP diets supplemented with EAAs or Avizyme maintain the same performance as that obtained from chicks fed diets containing recommended level of $\mathrm{CP}$. On the other hand, it can be concluded that $\mathrm{CP}$ can be reduced from the recommended level by $2 \%$ and supplement these diets with either EAAs or Avizyme without affecting performance. Besides, using such diets reduces feed cost.

2-Formulation based on bird amino acid requirements rather than $\mathrm{CP}$ can achieve optimal performance of broiler chickens and minimize $\mathrm{N}$ excretion by simply reducing total dietary $\mathrm{N}$ intake.

\section{REFERENCES}

Abdallah, A.G. (2005). A review on the new concept of ideal protein and amino acid profiles for broiler chicks. 3rd International Poultry Conference, 4-7 Apr. 2005 Hurghada - Egypt, 71-93.

Abd El-Gawad, A.M., M. O. Abd- Elsamee, Z. M. A. Abdo, and I. H. Salim (2004). Effect of dietary protein and some feed additives on broiler performance. Egypt. Poult. Sci., 24: 313-331.

Aftab, U., M. Ashraf, and Z. Jiang (2006). Low protein diets for broilers. World's Poult. Sci., 62: 688701.

Alam, M.R., F. Yoshizawa, and K. Sugahara (2014). Voluntary food intake variation in chickens on lysine-free diet is attributed to the plasma lysine concentration. Br. Poult. Sci., 55: 605-609.

Aletor, V. A., I.I. Hamid, E. Niess, and E. Pfeffer (2000). Low-protein amino acid-supplemented diets in broiler chickens: effects on performance, carcasscharacteristics, whole-body composition and efficiencies of nutrient utilisation. J. Sci. Food Agric., 80: 547-554.

Amerah, A.M., L.F. Romero, A. Awati, and V. Ravindran (2017). Effect of exogenous xylanase, amylase, and protease as single or combined activities on nutrient digestibility and growth performance of broilers fed corn/soy diets. Poult. Sci., 96: 807-816.

Angel, C.R., W. Saylor, S.L. Vieira, and N. Ward (2011). Effects of a monocomponent protease on performance and protein utilization in 7-to 22-day-old broiler chickens. Poult. Sci., 90: 2281-2286.

A.O.A.C. (1990). Association of Official Analytical Chemists, Official Methods of Analysis. 15th Edition, Washington, D.C, USA.

Asadi Kermani, Z., M.H. Shahir, and N. Baradaran (2017). Effect of gelatin supplementation on growth performance and blood metabolites of broiler chickens fed diets varying in crude protein. Livestock Science, 201: 5-12.

Baker, D. H., A. B. Batal, T. M. Parr, N. R. Augspurger, and C. M. Parsons (2002). Ideal ratio (relative to lysine) of tryptophan, threonine, isoleucine, and valine for chickens during the second and third weeks posthatch. Poult. Sci., 81:485-494.

Colonago, L., A. M. Penz, and L. S. Jensen (1991). Effect of response of starting broiler chicks to incremental reduction in intact protein on performance during growing Phase. Poult. Sci., 70 (Suppl.1): 153 (Abstr.).

Cowieson, A.J., and F.F. Roos (2014). Bioefficacy of a mono-component protease in the diets of pigs and poultry: a meta-analysis of effect on ileal amino acid digestibility. J. Appl. Anim. Nutr., 2: e13e20. 
Ding, X.M., D.D. Li, Z.R. Li, J.P. Wang, Q.F. Zeng, S.P. Bai, Z.W. Su, and K.Y. Zhang (2016). Effects of dietary crude protein levels and exogenous protease on performance, nutrient digestibility, trypsin activity and intestinal morphology in broilers. Livestock Science, 193: 26-31.

Dozier, W.A., and E.T. Moran (2002). Dimension and light reflectance of broiler breast fillets: influence of strain, sex, and feeding regimen. J. Appl. Poult. Res., 11: 202-208.

Duncan, D.B. (1955). Multiple range and multiple F tests. Biometrics, 11: 1-42.

Ferguson, N.S., R.S. Gates, J.L. Taraba, A.H. Cantor, A.J. Pescatore, M.J. Ford, and D.J. Burnham (1998). The effect of dietary crude protein on growth, ammonia concentration, and litter composition in broilers. Poult. Sci., 77: 1481-1487.

Freitas, D.M., S.L. Vieira, C.R. Angel, A. Favero, and A. Maiorka (2011). Performance and nutrient utilization of broilers fed diets supplemented with a novelmono-component protease. J. Appl. Poult. Res., 20: 322-334.

Garcia, N.M., G.M. Pesti, and R. I. Bakalli (2000). Influence of dietary protein level on the broiler Chicken's response to methionine and betaine supplements. Poult. Sci.,79:1478-1484.

Ghazi, S., J.A. Rooke, and H. Galbraith (2003). Improvement of the nutritive value of soybean meal by protease and a-galactosidase treatment in broilercockerels and broiler chicks. Br. Poult. Sci., 44: 410418.

Hidalgo, M. A., W. A. Dozier, A. J. Davis, and R. W. Gordon (2004). Live performance and meat yield responses to progressive concentrations of dietary energy maintained at a constant metabolizable energy-to-crude protein ratio. J. Appl. Poult. Res., 13:319-327.

Hilckling, D., W. Guenter, and M. E. Jackson (1990). The effect of dietary methionine and lysine on broiler chicken performance and breast meat yield. Can. J. Anim. Sci., 70: 673-678.

Holsheimer, J. P., and C. H. Veerkamp (1992). Effect of dietary energy, protein, and lysine content on performance and yield of two strains of male broiler chicks. Poult. Sci., 71: 872-879.

Kamran, Z., M. Sarwar, M. Nisa, M. A. Nadeem, S. Mahmood, M. E. Babar, and S. Ahmed (2008). Effect of Low-Protein Diets Having Constant Energy-to-Protein Ratio on Performance and Carcass Characteristics of Broiler Chickens from One to Thirty-Five Days of Age. Poult. Sci., 87:468-474

Kerr, B.J., and M.T. Kidd (1999). Amino acid supplementation of low-protein broiler diets: 1. Glutamic acid and indispensable amino acid supplementation. J.Appl. Poult. Res., 8: 298-309.

Khalaji, S., M. Manafi, Z. Olfati, M. Hedyati, M. latifi, and A. Veysi, (2016). Replacing soybean meal with gelatin extracted from cow skin and corn protein concentrate as a protein source in broiler diets. Poult. Sci., 95: 287-297.

Leung, P.M.B., and Q.R. Rogers (1969). Food intake: regulation by plasma amino acid pattern. Life Sci., 8: $1-9$.

Lipstein, B., and S. Bomstein (1975). The replacement of some of the soybean meal by the first limiting amino acids in practical broiler diets. 2. Special additions of methionine and lysine as partial substitutes for protein in finisher diets. Br. Poult. Sci., 16:189-200.

Liu, N., J.Q. Wang, K.T. Gu, Q.Q. Deng, and J.P. Wang (2017). Effects of dietary protein levels and multienzyme supplementation on growth performance and markers of gut health of broilers fed a miscellaneous meal based diet. Anim. Feed Sci. Technol., 234:110-117

Liu, S.Y., D.J. Cadogan, A. Peron, H.H. Truong, and P.H. Selle (2015). A combination of xylanase, amylase and protease influences growth performance nutrient utilization, starch and protein digestive dynamics in broiler chickens offered maize-, sorghum-and wheat-based diets. Anim. Prod. Sci., 55, 1255-1263.

Mahmood, T., M.A. Mirza, H. Nawaz, M. Shahid, M. Athar, and M. Hussain (2017). Effect of supplementing exogenous protease in low proteinpoultry by-product meal based diets on growth performanceand nutrient digestibility in broilers. Anim. Feed Sci. Technol., 228: 23-31

Marks, H.L. (1993). Carcass composition, feed intake and feed efficiency following long-term selection for four-week body weight in Japanese quail. Poul. Sci., 72: 1005-1011. 


\section{Emam}

Martinez, A. C., C. M. Parsons, and D. H. Baker (2006). Effect of microbial phytase and citric acid on phosphorus bioavailability, apparent metabolizable energy, and amino acid digestibility in distillers dried grains with solubles in chicks. Poult. Sci., 85:470-475

Mendonca, C. X., and L. Jensen (1989). Influence of valine level on performance of older broilers fed a low protein diet supplemented with amino acids. Nutr. Reports Intl., 40:247-252.

Moran, E.T, R.D. Bushong, and S.F. Bilgili (1992). Reducing dietary cmde protein for broilers while satisfying amino acid requirements by least-cost formulation: live performance, litter composition, and yield of fast-food carcass cuts at six weeks. Poult. Sci., 71:1687-1694.

National Research Council, NRC (1994). Nutrient Requirements of Poultry. 9th revised edition. National Academy Press. Washington, D.C., USA.

Naveed, A., T. Acamovic, and M.R. Bedford (1998). Effect of enzyme supplementation of UKknown Lupinus albus on growth performance in broiler chickens. Br. Poult. Sci., 39: S36-S37.

Nawaz, H., T. Mushtaq, and M. Yaqoob (2006). Effect of varying levels of energy and protein on live performance and carcass characteristics of broiler chicks. J. Poult. Sci., 43: 388-393.

Neto, M.G., G.M. Pesti, and R.I. Bakalli (2000). Influence of dietary protein level on the broiler chicken's response to methionine and betaine supplements. Poult. Sci., 79: 1478-1484.

North, M. O. (1981). Commercial Chicken Production Manual, $2^{\text {nd }}$ Edition. AVI Publishing Company Inc, USA.

Pan, L., Q.H. Shang, X.K. Ma, Y. Wu, S.F. Long, Q.Q. Wang, and X.S. Piao (2017). Coated compound proteases improve nitrogen utilization by decreasing manure nitrogen output for growing pigs fed sorghum soybean meal based diets. Anim. Feed Sci. Technol., 230: 136-142.

Pan, L., P.F. Zhao, Z.Y. Yang, S.F. Long, H.L. Wang, Q.Y. Tian, Y.T. Xu, X. Xu, Z.H. Zhang, and X.S. Piao (2016). Effects of coated compound proteases on apparent total tract digestibility of nutrients and apparent ileal digestibility of amino acids for pigs. Asian-Aust. J. Anim. Sci., 29: 1761-1767.

Parr, J. F., and J. D. Summers (1991). The effects of minimizing amino acid excesses in broiler diets. Poult. Sci. 70:1540-1549.

Radfar, M., A. Rogiewicz, and B.A. Slominski (2017). Chemical composition and nutritive value of canola-quality Brassica juncea meal for poultry and the effect of enzyme supplementation. Anim. Feed Sci. Technol., 225: 97-108.

Ragab, M. S., H. M. Abdel Wahed, E. M. Omar, and W. H. A. Mohamed (2012). Effect of adding citric and lactic acids to broiler diets different in their protein content on productive performance, bacterial count and some blood parameters. Egyptian J. Nutrition and Feeds, 15: 613-629.

Rahman, A., S. Ahmed, D. Khan, M. Hussain, I. Ahmad, Z. Shah, O. S. Mohammad, H. Ikram-Ul-Haq, and A. Zia-Ur-Rehman (2009). Nutritional importance of exogenous enzymes in broiler ration at finisher phase. Sarhad J. Agric. 25 (3), 475-478.

Recoules, E., H. Sabboh-Jourdan, A. Narcy, M. Lessire, G. Harichaux, V. Labas, M.J. Duclos, and S. Rehault-Godbert (2017) Exploring the in vivo digestion of plant proteins in broiler chickens. Poult. Sci., 96:1735-1747.

Schutte, J.B. (1987). Utilization of synthetic amino acids in poultry. Pages RT11-12 in: World's Poultry Science Association 6th European Symposium on Poultry Nutrition. Konigslutter, West Germany. Scott,

Selle, P.H., S.Y. Liu, J. Cai, and A.J. Cowieson (2013). Steam-pelleting temperatures, grain variety, feed form and protease supplementation of mediumly ground, sorghum-based broiler diets, influences on growth performance, relative gizzard weights, nutrient utilisation, starch and nitrogen digestibility. Anim. Prod. Sci., 53: 378-387.

Si, J., C. A. Fritts, D. J. Burnham, and P. W. Waldroup (2001). Relationship of dietary lysine level to the concentration of all essential amino acids in broiler diets. Poult. Sci., 80:1472-1479.

Si, J., C.A. Fritts, D.J. Burnham, and P.W. Waldroup (2004). Extent to which crude protein may be reduced in corn-soybean meal broiler diets through amino acid supplementation. Int. J. Poult. Sci., 3: $46-50$. 
Singh, A.K., J.F. Diaz Berrocoso, Y. Dersjant-Li, A. Awati, and R. Jha (2017). Effect of a combination of xylanase, amylase and protease on growth performance of broilers fed low and high fiber diets. Anim. Feed Sci. Technol., 232: 16-20.

Sterling, K. G., D. V. Vedenov, G. M. Pesti, and R. I. Bakalli (2005). Economically optimal crude protein and lysine levels for starting broiler chicks. Poult. Sci., 84:29-36.

Swennen, Q., G. P. J. Janssens, A. Collin, E. L. Bihan-Duval, K. Verbeke, E. Decuypere, and J. Buyse (2006). Diet-induced thermogenesis and glucose oxidation in broiler chickens: Influence of genotype and diet composition. Poult. Sci., 85:731-742.

Vieira, S.L., C. Stefanello, and H.S. Cemin (2016). Lowering the dietary protein levels by the use of syntheticamino acids and the use of a mono component protease. Anim. Feed Sci. Technol., 221: 262-266.

Waldroup, P. W., Q. Jiang, and C. A. Fritts (2005). Effects of supplementing broiler diets low in crude protein with essential and nonessential amino acids. Int. J. Poult. Sci., 4:425-431.

Waldroup, P.W., M.A. Motl, F. Yan, and C.A. Fritts (2006). Effects of betaine and choline on response to methionine supplementation to broiler diets formulatedto industry standards. J. Appl. Poult. Res., 15: 58-71.

Wang, J.J., J.D. Garlich, and J.C.H. Shih (2006). Beneficial effects of Versazyme, a keratinase feed additive, on body weight, feed conversion, and breast yield ofbroiler chickens. J. Appl. Poult. Res., 15: 544-550.

Xu, X., H.L. Wang, L. Pan, X.K. Ma, Q.Y. Tian, Y.T. Xu, S.F. Long, Z.H. Zhang, and X.S. Piao (2017). Effects of coated proteases on the performance, nutrient retention, gut morphology and carcass traits of broilers fed corn or sorghum based diets supplemented with soybean meal. Anim. Feed Sci. Technol., 223: 119-127.

Zaman, Q.U., T. Mushtaq, H. Nawaza, M.A. Mirza, S. Mahmood, T. Ahmad, M.E. Babar, and M.M.H. Mushtaq (2008). Effect of varying dietary energy and protein on broiler performance in hot climate. Anim. Feed Sci. Technol., 146: 302-312.

Zanella, I., N.K. Sakomura, F.G. Silversides, A. Figueiredo, and M. Pack (1999). Effect of enzyme supplementation of broiler diets based on corn and soybeans. Poult. Sci. 78, 561-568. 


\section{Emam}

\section{مستويات بروتين العليقة مع إضافة أو عدم إضافة الأحماض الأمينية المصنعة والإنزيم علي أداء بداري التسمين}

رمضان عحمد سلامة إمام

قسم إنتاج الاواجن - كلية الزراعة - جامعة الفيوم - مصر

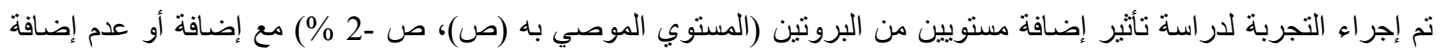

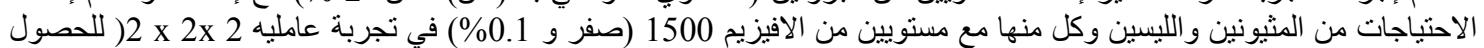

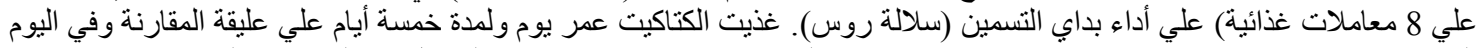

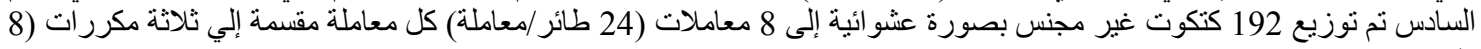

طائر /مكرر).

وتم تلخيص النتائج المتحصل عليها كما يلي :

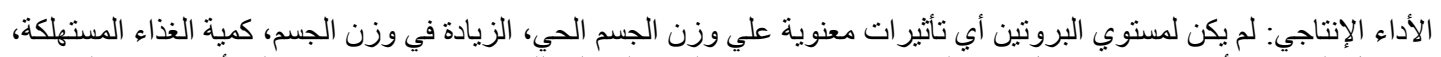

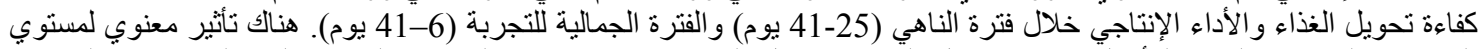

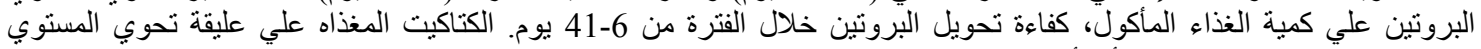

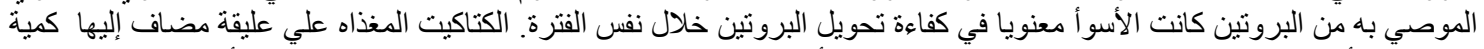

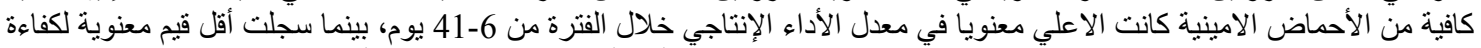

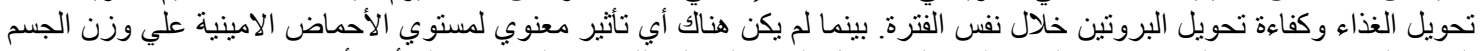

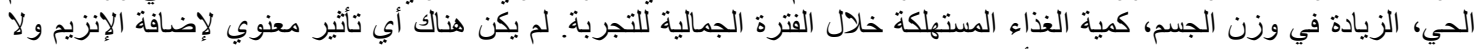

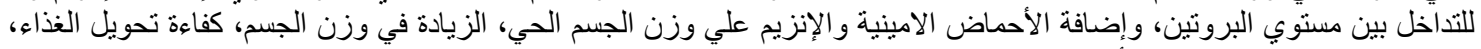

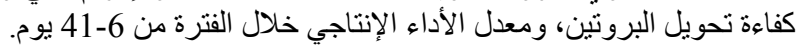

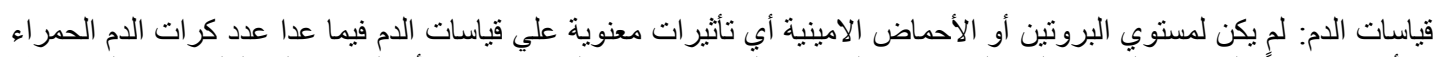

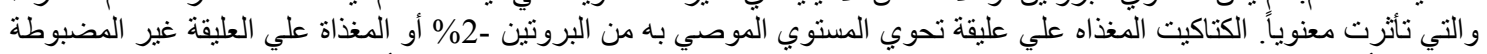

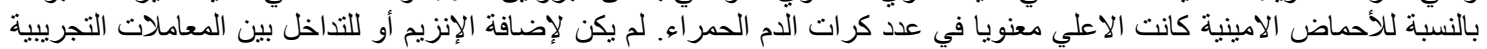

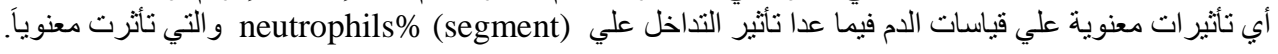

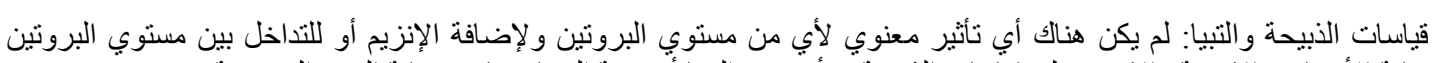

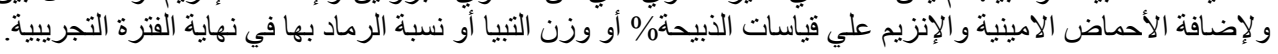

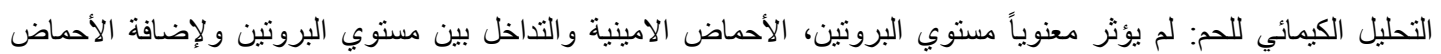
الامينية و الإنزيم علي التحليل الكيمائي للحم. لحنم.

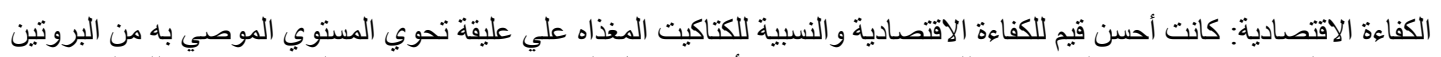

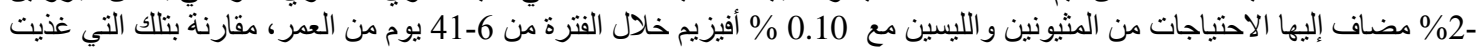
على عليقة المقارنة و المعاملات الاخريات

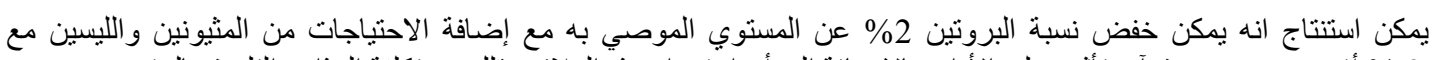

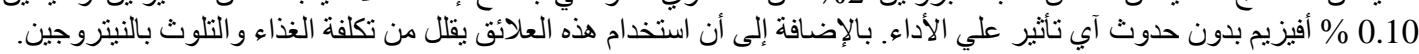

